\title{
CULTURE BASED EVALUATION OF MICROBIOTA IN CHILDREN WITH ACUTE APPENDICITIS
}

\author{
Juta Kroiča ${ }^{1}$, Aigars Reinis ${ }^{1}$, Mohit Kakar ${ }^{2,4, \#}$, Mathilde Delorme ${ }^{5}$, Renārs Broks ${ }^{1}$, \\ Lāsma Asare ${ }^{6}$, Marisa Berezovska ${ }^{2,4}$, Vladislavs Jansins ${ }^{1}$, Astra Zviedre ${ }^{2,4}$, \\ Arnis Enǵelis ${ }^{2,4}$, Amulya Saxena ${ }^{3}$, and Aigars Pētersons 2,4 \\ ${ }^{1}$ Department of Biology and Microbiology, 16 Dzirciema Str., Rīga Stradiṇš University, Rīga, LV-1007, LATVIA \\ 2 Department of Pediatric Surgery, Children's Clinical University Hospital, 45 Vienības Av., LV-1004, Rīga, LATVIA \\ ${ }^{3}$ Department of Pediatric Surgery, Chelsea Children's Hospital, Chelsea and Westminster NHS Fdn Trust, \\ Imperial College London, London, UK \\ ${ }^{4}$ Department of Pediatric Surgery, Rīga Stradinš University, 45 Vienības Av., Rīga, LV-1004, LATVIA \\ ${ }^{5}$ Faculty of Medicine, Rīga Stradinš̌ University, 16 Dzirciema Str., Rīga, LV-1007, LATVIA \\ ${ }^{6}$ Department of Statistics, Rīga Stradiṇš University, 23 Kapselu Str., Rīga, LV-1046, LATVIA \\ \# Corresponding author, mohitez@gmail.com
}

Contributed by Aigars Pētersons

Treatment strategies for acute uncomplicated appendicitis have evolved and now conservative antibacterial treatment is recommended over surgical treatment, especially for paediatric patients. The aim of this study was to evaluate microbiota in paediatric patients with acute uncomplicated and complicated appendicitis, and antibacterial susceptibility of the causative microorganisms. Bacteriological identification was conducted using the VITEK2 analyser. Antibacterial susceptibility tests were performed and the results were evaluated in accordance with the recommendations of the European Committee on Antimicrobial Susceptibility Testing (EUCAST) "Clinical breakpoints and dosing of antibiotics" (Version 7.0, January 2019). Serodiagnosis of Yersinia enterocolitica was performed using indirect haemagglutination. The results revealed differences in microbiota in cases of acute complicated and acute uncomplicated appendicitis. Pseudomonas aeruginosa was identified more frequently in cases of acute complicated appendicitis. Mixed culture was prevalent in cases of both acute complicated and acute uncomplicated appendicitis. Very few positive extended spectrum beta-lactamase (ESBL) Escherichia coli cultures were identified. Most of strains of Pseudomonas aeruginosa were resistant to amoxicillin with clavulanic acid, ertapenem, ampicillin and cefotaxime. Some of $\mathrm{E}$. coli isolates were resistant to ampicillin and to amoxicillin with clavulanic acid.

Key words: appendicitis, microbiota, Pseudomonas aeruginosa, Escherichia coli, extended spectrum beta-lactamase, antibacterial susceptibility.

\section{INTRODUCTION}

Acute appendicitis (AA) is one of the most common paediatric abdominal pathologies. It requires surgery, and despite advances in diagnostics and treatment, a uniform understanding of the aetiology and pathogenesis of appendicitis is still missing (Naher et al., 2013; Essenmacher et al., 2018; Snyder et al., 2018). The physiology of the appendix has also not been fully investigated. It is recognised that the vermiform appendix plays a role in the development and maturation of the immune system (Gebbers and Laissue, 2004; Rhee et al., 2005). Involvement of microbes in the pathogenesis of appendicitis is not entirely understood; however, recent research suggests that the appendix functions as a microbiota reservoir in the gastrointestinal tract. The belief is that it ensures the repopulation of microbiota 
during acute illnesses, in which the gastrointestinal tract is colonised by pathogens such acute gastroenteritis, and after antibacterial treatment (Guinane et al., 2013).

Historically, the only effective treatment method of appendicitis and prevention of septic complications has been surgery, namely, an appendectomy, which has been practiced for over 130 years (Rogers et al., 2016). This view has been challenged in recent years as conservative treatment using antibiotics has supplanted surgical interventions (Lamps, 2010). Clinical research has demonstrated the efficacy of antibacterial treatment, but nonetheless, $27 \%$ of patients each year still require surgery (Roberts, 1988).

One of the most important issues in paediatric surgery is distinguishing between acute uncomplicated appendicitis (AnA) and acute complicated appendicitis (AcA) upon commencing conservative treatment, as complicated cases indicate a delay in establishing diagnosis and require emergency surgery. These cases constitute more than $35 \%$ of all AA cases in Latvia. Our current research showed that the total number of AA cases treated surgically at the Children's Clinical University Hospital has not changed, but there has been an increased incidence of AcA (Kakars et al., 2017). Increase use of conservative treatment necessitates the evaluation of algorithms for antibacterial treatment, as they can differ among clinical institutions (Salo et al., 2017).

The aim of this study was to evaluate microbiota in paediatric patients with acute uncomplicated and complicated appendicitis, and antibacterial susceptibility of the causative microorganisms.

\section{MATERIALS AND METHODS}

This study included children between the ages of seven and 17 admitted to the Children's Clinical University Hospital due to acute abdominal pain with signs and symptoms suggesting the possibility of appendicitis. All patients were examined to confirm or exclude this diagnosis. Preoperative screening involved physical examination, complete blood count, abdominal ultrasound (US) and detection of serum values of C-reactive protein (CRP) and interleukin-6 (IL-6).

The paediatric surgery team supervising patients with appendicitis received a written consent form from the caregiver and assent from the patient if they were 13 years of age or older. The consent form provided information to the patient and the caregiver about the research objective and methodology used for examining the biological material.

Ethical approval: All procedures performed in this study involving human participants were in accordance with the ethical standards of the institutional and/or national research committee (Rīga Stradiňš University; reference number: 21/27.04.2017; and Children's Clinical University Hospital; reference number: SP-37/2018), and with the 1964 Helsinki declaration and its later amendments or comparable ethical standards. Informed consent was obtained from a parent of each individual participant included in the study. Clinical data collected prior to surgery included patients' age, sex, and current medical history.

Altogether, a total of 67 patients were eligible and recruited for this study. All of these patients had an appendectomy, and either laparoscopic or conventional laparotomy was performed in all of the patients. Intraoperatively, a microbiological culture swab from the peritoneal cavity was collected. After the removal of the appendix, an extra submucosal swab was taken to avoid bacterial dissemination from the following swabs. The appendix was dissected longitudinally and under sterile conditions, and swab samples were taken from the distal and proximal part of the appendiceal lumen. Each pair was placed in Amies medium for immediate transfer and subsequent bacterial culture (Schulin et al., 2017). They were cultivated under aerobic and anaerobic conditions. Cultivation was performed on blood agar (Supplement, Oxid, UK; defibrinated sheep blood - E\&O laboratories limited, Scotland), MacConkey (Oxid, UK) and tripticase soy (Oxid, UK) agar. Bacterial identification was performed using the VITEK2 analyser (Biomerieux, France).

Antibacterial susceptibility tests were performed and the results were evaluated in accordance with the recommendations of the European Committee on Antimicrobial Susceptibility Testing (EUCAST), "Clinical breakpoints and dosing of antibiotics" (Version 7.0, January 2019) (Anonymous, 2019). Overnight cultures were suspended in physiological saline to $0.5 \mathrm{McF}$ arland units (McFarland Densitometer DEN-1, Biosan, Latvia). The suspension was inoculated on Mueller-Hinton agar (Oxid, UK). Selected antibiotics were placed on the inoculated plates and included ceftazidime $10 \mu \mathrm{g}$, ampicillin $10 \mu \mathrm{g}$, cefotaxime $5 \mu \mathrm{g}$, meropenem $10 \mu \mathrm{g}$, imipenem $10 \mu \mathrm{g}$, amikacin $30 \mu \mathrm{g}$, gentamicin $10 \mu \mathrm{g}$, ciprofloxacin $5 \mu \mathrm{g}$, chloramphenicol $30 \mu \mathrm{g}$, ertapenem $10 \mu \mathrm{g}$, amoxicillin+clavulanic acid $30 \mu \mathrm{g}$, and piperacillin+tazobactam $36 \mu \mathrm{g}$ (Liofilchem, Italy). The plates were incubated at $+35 \pm 1^{\circ} \mathrm{C}$ temperature for $18 \pm 2 \mathrm{~h}$. A double disk synergy test (DDST) was used to confirm extended spectrum beta-lactamase (ESBL). Disks containing cephalosporins (cefotaxime, ceftazidime) were applied to plates next to a disk with clavulanic acid (amoxicillinclavulanic acid). A positive result was indicated if the inhibition zones around any of the cephalosporin disks were augmented in the direction of the disk containing clavulanic acid. Results were evaluated by measuring the zone of inhibition, and resistance was interpreted in accordance with the EUCAST breakpoints.

Haematoxylin-eosin staining was performed and the grade of inflammation was assessed, differentiating gangrenous and phlegmonous appendicitis. Serodiagnosis of Yersinia enterocolitica was performed using indirect (passive) haemagglutination.

For statistical analysis, Microsoft Excel 2016 and IBM SPSS Statistics 22 were employed. Results were expressed as median values and interquartile ranges (IQR). The com- 
parison between groups was made using both the MannWhitney U-Test (two groups) and Kruskal-Wallis test (three groups) for non-parametric distribution, and the Fisher Exact Test was applied on normally distributed variables to determine correlations between them. A $p$-value of $<0.05$ was considered statistically significant. The data was entered in SPSS and validated by an additional statistical analyst for accuracy.

\section{RESULTS}

A total of 67 children having arrived at the Emergency Department were included in this study (33 males, 34 females). Patient age ranged 7-17 years with a median age of 12 years. Depending on the intraoperative and bacteriological findings, two patient groups were established (Table 1). Patients with positive culture from samples of the peritoneal cavity were classified in the AcA group, which consisted of 34 patients $(50.7 \%)$. Those patients with a negative culture were classified in the AnA group, which consisted of 33 patients $(49.3 \%)$. There was no statistically significant difference between the results of the samples taken from the anatomical parts of the appendiceal lumen. E. coli was the prevalent representative of appendiceal intraluminal microbiota in both complicated and uncomplicated cases, totalling 51 patients $(76.0 \%)$. $P$. aeruginosa was the prevalent microorganism of the extraluminal appendiceal microbiota (AcA/AuA:13/1). There were some differences in microbiota of the proximal and distal parts of the appendix between patients with acute complicated and acute uncomplicated appendicitis. In 22 of 34 AcA cases (55.0\%) microbiota were identical, but the microbiota in distal and proximal parts differed for the remaining 12 cases (35.0\%).

Bacteria were grown from samples of submucosa in both acute complicated and uncomplicated appendicitis. E. coli was the prevalent species, with $P$. aeruginosa being the second most commonly isolated microorganism (Table 1). Histological examination of surgically removed specimens showed a significant correlation between gangrenous appendicitis in AcA and phlegmonous appendicitis in AnA (Chi-square $=15.246$, df $=1, p<0.001$ ). More than a half of the patients $(61.3 \%)$ who had a drainage tube inserted were diagnosed with AcA $(p=0.004)$. A simple comparison suggested that AnA had a slightly shorter median postoperative hospital stay of five versus six days. Yersinia enterocolitica antibody detection preoperatively was negative in all cases. The remaining demographics and clinical characteristics of the patients are shown in Table 2.

Bacterial culture resulted in positive intraluminal samples with growth of one or several strains from each appendix. Table 2 shows the number of cases of the most common isolates for the AcA and AnA patient groups. Frequently, mixed strains were found at culture. The most common bacteria isolated from the appendix were Escherichia coli in 46 (37.4\%), followed by Pseudomonas aeruginosa in 16 (13.0\%), Klebsiella pneumoniae in nine (7.3\%), Bacterioides fragilis in six (4.9\%), and Citrobacter braakii in four
Table 1. Types of isolated bacteria, frequency and percentage in acute complicated appendicitis and acute uncomplicated appendicitis

\begin{tabular}{|c|c|c|c|c|c|c|}
\hline & \multicolumn{2}{|c|}{ AcA } & \multicolumn{2}{|c|}{ AnA } & \multirow{2}{*}{$\begin{array}{c}\text { Total } \\
\text { isolates No. }\end{array}$} & \multirow[t]{2}{*}{$p$-value } \\
\hline & No. & $\%$ & No. & $\%$ & & \\
\hline Escherichia coli & 24 & 47.1 & 27 & 52.9 & 51 & $0.460^{\#}$ \\
\hline $\begin{array}{l}\text { Pseudomonas } \\
\text { aeruginosa }\end{array}$ & 13 & 92.9 & 1 & 7.1 & 14 & $0.098 *$ \\
\hline Klebsiella pneumoniae & 3 & 50.0 & 3 & 50.0 & 6 & 0.480 \\
\hline Citrobacter braakii & 0 & 0 & 3 & 100.0 & 4 & $0.053 *$ \\
\hline Bacterioides fragilis & 1 & 20.0 & 4 & 80.0 & 5 & 0.321 \\
\hline Mixed cases & 23 & 51.1 & 22 & 48.9 & 45 & 0.867 \\
\hline Total & 60 & & 63 & & 123 & \\
\hline
\end{tabular}

AcA, acute complicated appendicitis; AnA, acute uncomplicated appendicitis, " Pearson Chi-square test, * Fisher Exact test

Table 2. Characteristics and distribution of the study population

\begin{tabular}{lccccc}
\hline & AcA & AnA & Total & $p$-value \\
\hline Children, n (\%) & $34(50.7)$ & $33(49.3)$ & 67 & 0.288 \\
Age, median (IQR) & $12(9-15)$ & $11(10-15)$ & - & 0.200 \\
Laboratory values & & & & \\
$\quad$ WBC count $\left(\times 10^{9} / 1\right)$, & 16.7 & 14.5 & - & $<0.001$ \\
$\quad$ CRP $(\mathrm{g} / \mathrm{l})$, & 27.6 & 10.3 & - & 0.050 \\
Duration of symptoms, h (IQR) & $28(16-51)$ & $20(12-26)$ & - & 0.038 \\
Alvarado score, points & 8 & 7 & - & $<0.001$ \\
Type of surgery, n $(\%)$ & & & & \\
$\quad$ Laparotomy & $7(63.6)$ & $4(36.4)$ & 11 & 0.349 \\
$\quad$ Laparoscopy & $26(48.1)$ & $28(51.9)$ & 54 & \\
Histology, n $(\%)$ & & & & \\
$\quad$ Phlegmonous & $10(29.4)$ & $24(70.6)$ & 34 & $<0.001$ \\
$\quad$ Gangrenous & $23(74.2)$ & $8(25.8)$ & 31 & \\
Drainage tube, n $(\%)$ & $19(70.4)$ & $8(29.6)$ & 27 & 0.008 \\
Length of hospital stay, days & $6(5-9)$ & $5(4-6)$ & - & 0.006
\end{tabular}
(IQR)

AcA, acute complicated appendicitis; AnA, acute uncomplicated appendicitis; IQR, interquartile range; WBC, white blood cells; CRP, C-reactive protein. Median values are presented with IQR $(25 \%, 75 \%)$

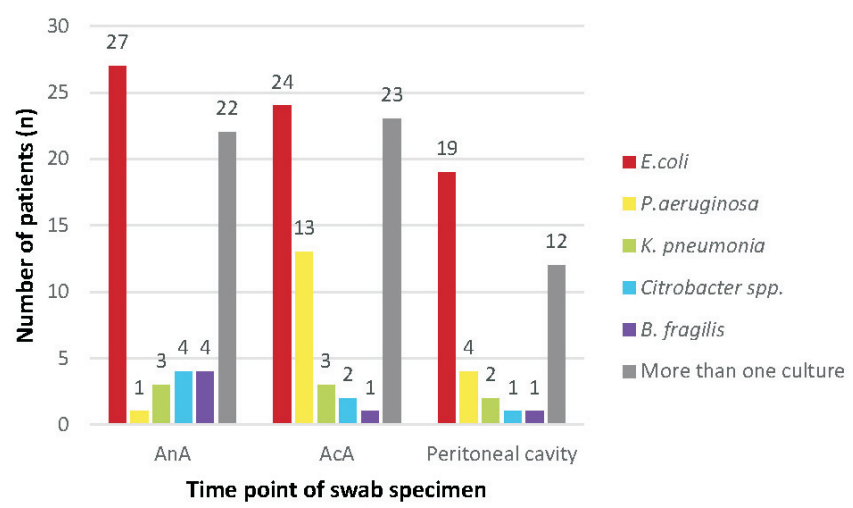

Fig 1. Types of organisms isolated.

samples (3.3\%) (Table 2, Fig. 1). The 46 samples isolating E. coli had various antibacterial sensitivities: four $(\sim 8.7 \%)$ strains were resistant to ceftazidime; $17(\sim 37 \%)$ to ampicillin; three $(\sim 6.5 \%)$ to cefotaxime; one $(\sim 2.17 \%)$ to imipenem; four $(\sim 8.7 \%)$ to ciprofloxacin; three $(\sim 6.5 \%)$ to chloramphenicol; two $(\sim 4.34 \%)$ to ertapenem; nine $(\sim 19.5 \%)$ to 
amoxicillin/clavulanic acid, and two ( 4.34\%) to piperacillin-tazobactam. All strains were susceptible to meropenem, amikacin and gentamicin. Additionally, two ESBL-producing strains of $E$. coli were also isolated.

P. aeruginosa was isolated from 15 samples. Antibacterial resistance was shown for four $(26.7 \%)$ strains to ceftazidime; $11(73.3 \%)$ to ampicillin; eight $(53.3 \%)$ to cefotaxime; five $(33.3 \%)$ to imipenem; five $(33.3 \%)$ to chloramphenicol; $11(73.3 \%)$ to ertapenem; $11(73.3 \%)$ to amoxicillin/clavulanic acid and one (6.67\%) to piperacillin-tazobactam. All strains were susceptible to meropenem, amikacin, gentamicin and ciprofloxacin. Other bacteria from the Enterobacteriaceae family were also isolated, such as Citrobacter spp., Klebsiella spp., and others. Citrobacter spp. were resistant to amoxicillin/clavulanic acid, and Klebsiella spp. were resistant to ampicillin.

\section{DISCUSSION}

Research has shown that appendiceal luminal obstruction, by creating a closed loop, is the cause of appendicitis. Lymphoid hyperplasia in the follicles of the submucosa is the typical cause of luminal obstruction in children. Faecolith is mentioned as a precipitating obstructive factor (Bhangu et al., 2015), while parasites (e.g. nematodes) and inflammatory constrictions are less common causes. Obstruction leads to increased bacterial proliferation, thus increasing the intraluminal pressure that subsequently impedes blood flow, which results in congestion and ischemia that promotes bacterial colonisation.

Although obstruction is the leading theory behind pathogenesis of appendicitis, it is not fully consistent with the data obtained in research and clinical practice. Therefore, bacteria are believed to also play a role in the pathogenesis. There is also a hypothesis highlighting the importance of genetic predisposition as the prevalence of appendicitis is higher among first-degree relatives. Finally, perforated and non-perforated appendicitis, which represent disease progression from an early to a late stage, are epidemiologically recognised as two distinct processes (Bhangu et al., 2015; Abdussemee et al., 2018; Essenmacher et al., 2018). There is a dispute regarding whether the most common causative agents are E. coli and anaerobic Clostridium perfringens (Abdussemee et al., 2018), as opposed to Klebsiella spp. and Enterobacter spp. (Parthiban and Harish 2017), or Bacteroides fragilis, Pseudomonas aeruginosa and Peptostreptococcus spp. (Roberts, 1988; Lamps, 2010; GuilletCaruba et al., 2011; Chen et al., 2012).

The results of our study demonstrated that $53.0 \%$ of $P$. aeruginosa isolates were resistant to cefotaxime, and about a third against ceftazidime. Cefotaxime is included in the guidelines of the Children's Clinical University Hospital for treatment of intraperitoneal infections in paediatric patients (Anonymous, 2013). Although both antibiotics belong to third generation cephalosporins, ceftazidime has shown more efficacy in the treatment of infections with gram nega- tive bacteria, especially Pseudomonas spp., an important causative agent of nosocomial infections (Anonymous, 2019). Treatment typically involves the use of beta-lactam antibiotics; however, ceftazidime is the most important antibacterial agent, which functions as a cell wall synthesis inhibitor by binding to penicillin-binding protein 3 (PBP3) (Koss et al., 2016). Nevertheless, ceftazidime-resistant strains have been discovered. Resistance mechanisms against ceftazidime in $P$. aeruginosa include the production of beta-lactamase encoded by genes acquired via horizontal gene transfer, or by increased production of a drug-induced, broad-spectrum, chromosomally encoded class $\mathrm{C}$ beta lactamase with an altered affinity (Fisher and Mobashery, 2014). The frequency of resistance against ceftazidime in isolates can fluctuate between $35 \%$ to $86 \%$ (Du et al., 2010; Noha et al., 2015).

In our study, $P$. aeruginosa was prevalent in samples obtained from patients with acute complicated appendicitis. All strains were sensitive to meropenem, which inhibits cell wall synthesis and is not affected by beta-lactamase (Baldwin et al., 2008). Drusano et al. (2018) investigated the potential use of fosfomycin in the treatment of infections with $P$. aeruginosa and discovered that the bacteria rapidly developed resistance against fosfomycin. Therefore, they suggested switching treatment from monotherapy to combination therapy with fosfomycin and meropenem. A synergistic effect was observed with fosfomycin eradicating the meropenem-resistant mutants and meropenem working against fosfomycin-resistant strains. Thus, this combination was recommended as a treatment strategy for wider use in the future (Drusano et al., 2018). Another combination displaying promising results in research settings is meropenem in conjunction with ceftazidime (Feng et al., 2017). In the past decade, the following antibiotic combinations have been investigated as potential treatment options (Gracia et al. 2018).

Ceftazidime-Avibactam. Avibactam is a member of the class of azabicycloalkanes. Avibactam is a non-beta-lactam beta-lactamase inhibitor that is available in combination with ceftazidime (Avycaz). This combination was approved by the Food and Drug Administration (FDA) on 25 February 2015 for the treatment of complicated intra-abdominal infections in combination with metronidazole (Anonymous, 2019). This combination has shown efficacy of up to $90 \%$ against ceftazidime-resistant strains of $P$. aeruginosa (Mazuski et al., 2016; Qin et al., 2017). Combined treatment with ceftazidime-avibactam and colistin has shown promise in treating infections with XDR (extremely drug-resistant) P. aeruginosa (Xipell et al, 2017).

Ceftolozane-Tazobactam. Ceftolozane-tazobactam was approved by the FDA in 2014, shortly before ceftazidimeavibactam was approved for the same indications. It is highly effective in combinations with meropenem and levofloxacin (Solomkin et al., 2015; Wagenlehner et al., 2015; Gracia et al., 2018).

In our study, amikacin demonstrated significant efficacy against isolates from samples. It is a broad-spectrum semi- 
synthetic aminoglycoside antibiotic, derived from kanamycin with antimicrobial properties. Amikacin irreversibly binds to the bacterial $30 \mathrm{~S}$ ribosomal subunit, specifically locking 16S rRNA and S12 protein within the 30S subunit. This leads to interference with the translational initiation complex and misreading of mRNA, thereby hampering protein synthesis and resulting in the bactericidal effect. This agent is usually used in short-term treatment of serious infections due to susceptible strains of Gram-negative bacteria (Anonymous, 2019). Data is scarce regarding amikacin-resistant pseudomonas. Research conducted by Loho et al. (2018) showed that only two of 20 P. aeruginosa isolates were resistant against amikacin. Its combination with doripenem is synergistic and improves treatment results.

The most commonly isolated microorganism from our patients' samples was E. coli, especially from those treated for acute uncomplicated appendicitis. This finding concurs with results obtained by other authors (Naher et al., 2013; Bhangu et al., 2015; Abdussemee et al., 2018; Bazzaz et al., 2018; Essenmacher et al., 2018; Rickard et al., 2018; Snyder et al., 2018; Turel et al., 2018). Our data revealed that strains of $E$. coli are sensitive to antibacterial agents such as amikacin, imipenem, and meropenem, which is in line with recent studies by other researchers (Bazzaz et al., 2018). There were strains resistant against other antibacterial agents included in the treatment guidelines; three and four of 47 were resistant to cefotaxime and ceftazidime, respectively. Only two isolates were ESBL-positive. This complies with data from other studies that showed the prevalence of ESBL-producing E. coli in Latvia. $11 \%$ of E. coli present in animal microbiota produce ESBL (Terentjeva et al., 2019), whereas in the adult population, ESBL are produced by only $1.6 \%$ of $E$. coli (Ny et al., 2018).

\section{CONCLUSIONS}

In cases of acute complicated appendicitis, $P$. aeruginosa is the prevalent microorganism, whereas $E$. coli is the most commonly isolated microorganism in acute uncomplicated appendicitis. Antibiotic treatment strategies in cases of acute complicated appendicitis should include antibiotics with different mechanisms of action to achieve a synergistic effect and prevent the development of antibiotic resistance. Mixed culture results were prevalent in both acute complicated and acute uncomplicated appendicitis. The incidence of ESBL producing microorganisms was low in these acute appendicitis cases.

\section{ACKNOWLEDGEMENTS}

The authors would like to acknowledge every single person including the Latvian Council of Science and Rīga Stradiňš University for their sincere contribution in funding this project. The study was funded by the Latvian Academy of Sciences and Rìga Stradiňš University.

\section{CONFLICT OF INTEREST}

The authors declare that they have no conflict of interest.

\section{REFERENCES}

Abdussemee, A., Oludolapo, A., Adeyinka, A., Olusegun, F. (2018). Bacterial pattern in acute appendicitis. Ann. Afr. Surg., 15 (1), 8-13.

Anonymous (2013). Recommendations for preoperative antimicrobial prophylaxis. Recommendations for the use of antibacterial agents in surgical prophylaxis KS/MET-43-00/2013. Children's Clinical University Clinic, pp. 9.

Anonymous (2019). Clinical breakpoints and dosing of antibiotics. European Committee on Antimicrobial susceptibility testing.

http://www.eucast.org/clinical_breakpoints/ (accessed 10 December 2019).

Anonymous (2019). National Center for Biotechnology Information. PubChem Database. Avibactam, CID=9835049.

https://pubchem.ncbi.nlm.nih.gov/compound/Avibactam (accessed $10 \mathrm{De}-$ cember 2019).

Anonymous (2019). National Center for Biotechnology Information. PubChem Database.Amikacin,CID=37768.

https://pubchem.ncbi.nlm.nih.gov/compound/Amikacin (accessed 12 December 2019).

Anonymous (2019). The Drugbank. Ceftazidime.

https://www.drugbank.ca/drugs/DB00438 ( accessed 10 December 2019).

Baldwin, C. M., Lyseng-Williamson, K. A., Keam, S. J. (2008). Meropenem: A review of its use in the treatment of serious bacterial infections. Drugs, 68 (6), 803-838.

Bazzaz, A., Lor, D., Mahdi, N. (2018). Impact of some antibiotics on bacteria isolated from appendices in Kirkuk Province, Iraq. Adv. Biosci. Biotechnol., 9, 1-10.

Bhangu, A., Søreide, K., Di Saverio, S., Assarsson, J. H., Drake, F. T. (2015). Acute appendicitis: Modern understanding of pathogenesis, diagnosis, and management. Lancet, 386 (10000), 1278-1287.

Chen, C. Y., Chen, Y. C., Pu, H. N., Tsai, C. H., Chen, W. T., Lin, C. H. (2012). Bacteriology of acute appendicitis and its implication for the use of prophylactic antibiotics. Surg. Infect. (Larchmt), 13 (6), 383-390.

Drusano, G. L., Neely, M. N., Yamada, W.M., Duncanson, B., Brown, D., Maynard, M., Vicchiarelli, M., Louie, A. (2018). The combination of fosfomycin plus meropenem is synergistic for Pseudomonas aeruginosa PAO1 in a hollow-fiber infection model. Antimicrob. Agents Chemother., 62 (12), e01682-18.

Du, S.-J., Kuo, Cheng, C. H., Fei, A., Wei, H.-W., Chang, S.-K. (2010). Molecular mechanisms of ceftazidime resistance in Pseudomonas aeruginosa isolates from canine and human infections. Original Paper Veterin. Med. 55, 172-182.

Essenmacher, A. C., Nash, E., Walker, S. K., Pitcher, G. J., Buresh, C. T., Sato, T. S. (2018). Stump appendicitis. Clin. Pract. Cases Emerg. Med., 2 (3), 211-214.

Feng, Y., Bakker, R. T., van Hest, R. M., Hodiamont, C. J., Brul, S., Schultsz, C., ter Kuile, B. H. (2017). Optimization of therapy against Pseudomonas aeruginosa with ceftazidime and meropenem using chemostats as model for infections, FEMS Microbiol. Lett., 364 (14), fnx142.

Fisher, J. F., Mobashery, S. (2014). The sentinel role of peptidoglycan recycling in the $\beta$-lactam resistance of the Gram-negative Enterobacteriaceae and Pseudomonas aeruginosa. Bioorg. Chem., 56, 41-48.

Gebbers, J. O., Laissue, J. A. (2004). Bacterial translocation in the normal human appendix parallels the development of the local immune system. Ann. NY Acad. Sci., 1029, 337-343.

Gracia, J., Gruenberg, K., Nguyen, L., MacDougall, C. (2018). Multidrug-resistant Pseudomonas aeruginosa Iinfections: Hard to treat, but hope on the horizon? Contagion Live - Infectious Diseases Today, received from ContagionLive, Database on the World Wide Web.

https://www.contagionlive.com/publications/contagion/2018/february/ multidrugresistant-pseudomonas-aeruginosa-infections-hard-to-treat-buthope-on-the-horizon (accessed 10 December 2019).

Guillet-Caruba, C., Cheikhelard, A., Guillet, M., Bille, E., Descamps, P., Yin, L., Khen-Dunlop, N., Zahar, J. R., Sarnacki, S., Revillon, Y., Berche, P., Ferroni, A. (2011). Bacteriologic epidemiology and empirical treatment 
of pediatric complicated appendicitis. Diagn. Microbiol. Infect. Dis., 69 (4), 376-381.

Guinane, C. M., Tadrous, A., Fouhy, F., Ryan, C. A., Dempsey, E. M., Murphy, B., Andrews, E., Cotter, P. D., Stanton, C., Ross, R. P. (2013). Microbial composition of human appendices from patients following appendectomy. MBio., 4 (1), e00366-12.

Jackson, H. T., Mongodin, E. F (2014). Culture-independent evaluation of appendix and rectum microbiomes in children with and without appendicitis. PLOS One, 9 (4), 1-9.

Kakars, M., Rekevica, A., Engelis, A., Petersons, A. (2017). An update of a single center review in the management of acute appendicitis in children. In: International Scientific Conference, 6-7 April 2017, Rīga, Latvia. Rīga Stradiņš University, Rīga, p. 59

Kos V. N., McLaughlin R. E., Gardner H. A. (2016). Elucidation of mechanisms of ceftazidime resistance among clinical isolates of Pseudomonas aeruginosa by using genomic data. Antimicrobial agents and chemotherapy, 60 (6), 3856-3861.

Lamps, L. W. (2010). Infectious causes of appendicitis. Inf. Dis. Clin. North Amer., 24 (4), 995-1018-ix-X.

Loho, T., Sukartini, N., Astrawinata, D. A. W, Immanuel, S., Aulia, D., Priatni, I. (2018). In vitro antibacterial interaction of Doripenem and Amikacin against multidrug-resistant Acinetobacter baumannii, Pseudomonas aeruginosa, and Klebsiella pneumoniae isolates. Can. J. Infect. Dis. Med. Microbiol. Article ID 1047670, 6 pages. https://doi.org/10.1155/2018/1047670.

Mazuski, J. E., Gasink, L. B., Armstrong, J., Broadhurst, H., Stone, G. G., Rank, D., Llorens, L., Newell, P., Pachl, J. (2016). Efficacy and safety of ceftazidime-avibactam plus metronidazole versus meropenem in the treatment of complicated intra-abdominal infection: Results from a randomized, controlled, double-blind, phase 3 program. Clin. Infect. Dis., 62 (11), 1380-1389.

Naher, H. S., Ktab, F. K. (2013). Bacterial profile associated with appendicitis. Int. Res. J. Medical Sci., Vol. 1 (2), 1-4.

Noha, A. H., Amany, H. I. M., Sahar,M. A. E., Hazem, A. W. A. R. (2015). High prevalence of multidrug resistant Pseudomonas aeruginosa recovered from infected burn wounds in children. Arch. Clin. Microbiol., 4 (4), $1-7$.

Ny, S., Kozlov, R., Dumpis, U., Edquist, P., Gröndahl-Yli-Hannuksela, K., Kling, A. N., Lis, D. O., Lübbert, C., Pomorska-Wesołowska, M., Palagin, I., Vilde, A., Vuopio, J., Walter, J., Wisell, K.T., Tegmark, K., NoDARS ESBL-carrier working group. (2018). Large variation in ESBL-producing Escherichia coli carriers in six European countries including Russia. Eur. J. Clin. Microbiol. Infect. Dis., 37, 2347-2354.

Parthiban, N., Harish, M. (2017). A study on microbiology culture of acute appendicectomy specimen and its correlation with wound infection. Int. Surg. J., 4, 2212-2215.

Qin, X., Tran, B. G., Kim, M. J., Wang, L., Nguyen, D. A., Chen, Q., Song J., Laud, P. J., Stone, G. G. Chow, J. W. (2017). A randomised, double-blind, phase 3 study comparing the efficacy and safety of ceftazidime/avibactam plus metronidazole versus meropenem for complicated intra-abdominal in- fections in hospitalised adults in Asia. Int. J. Antimicrob. Agents, 49 (5), 579-588.

Rhee, K. J., Jasper, P. J., Sethupathi, P., Shanmugam, M., Lanning, D., Knight, K. L. (2005). Positive selection of the peripheral B cell repertoire in gut-associated lymphoid tissues. J. Exp. Med., 201 (1), 55-62.

Rickard, J. (2018). Antibiotic use and antimicrobial resistance of surgical patients with peritonitis at a tertiary referral hospital in Rwanda. Surg. Infect., 19 (4), 382-387.

Roberts, J. P. (1988). Quantitative bacterial flora of acute appendicitis. Arch. Dis. Childhood, 63 (5), 536.

Rogers, M. B., Brower-Sinning, R., Firek, B., Zhong, D., Morowitz, M. J. (2016). Acute appendicitis in children is associated with a local expansion of fusobacteria. Clin. Infect. Dis., 63 (1), 71-78.

Salö, M., Marungruang, N., Roth, B., Sundberg, T., Stenström, P., Arnbjörnsson, E., Fåk, F., Ohlsson, B. (2017). Evaluation of the microbiome in children's appendicitis. Int. J. Colorectal Dis., 32 (1) $19-28$

Schulin, S., Schlichting, N., Blod, C., Opitz, S., Suttkus, A., Stingu, C. S. Barry, K., Lacher, M., Bühligen, U., Mayer, S. (2017). The intra- and extraluminal appendiceal microbiome in pediatric patients. Medicine, $\mathbf{9 6}$ 52(e9518)

Snyder, M. J., Guthrie, M., Cagle, S. (2018). Acute appendicitis: Efficient diagnosis and management. Amer. Fam. Physician, 98 (1), 25-33.

Solomkin, J., Hershberger, E., Miller, B., Popejoy, M.., Friedland, I., Steenbergen, J., Yoon, M., Collins, S., Yuan,G., Barie, P. S., Eckmann, C. (2015). Ceftolozane/tazobactam plus metronidazole for complicated intra-abdominal infections in an era of multidrug resistance: results from a randomized, double-blind, phase 3 trial (ASPECT-cIAI). Clin. Infect. Dis., 60 (10), 1462-1471

Terentjeva, M., Streikiša, M., Avsejenko, J., Trofimova, J., Kovaḷenko, K., Elferts, D., Bērziňš, A. (2019). Prevalence and antimicrobial resistance of Escherichia coli, Enterococcus spp. and the major foodborne pathogens in calves in Latvia. Foodborne Pathog. Dis., 16 (1), 35-41.

Turel, O. Mirapoglu, S. Y., Yuksel, M., Ceylan, A., Gultepe, B. S. (2018) Perforated appendicitis in children: Antimicrobial susceptibility and antimicrobial stewardship. J. Global Antimicrob. Resist., 16, 159-161.

Wagenlehner, F. M., Umeh, O., Steenbergen, J., Yuan, G., Darouiche, R. O. (2015). Ceftolozane-tazobactam compared with levofloxacin in the treatment of complicated urinary tract infections, including pyelonephritis: A randomised, double-blind, phase 3 trial (ASPECT-cUTI). The Lancet, 385 (9981), 1949-1956.

Xipell, M., Bodro, M., Marco, F., Losno, R. A., Cardozo, C., Soriano, A. (2017). Clinical experience with ceftazidime/avibactam in patients with severe infections, including meningitis and lung abscesses, caused by extensively drug-resistant Pseudomonas aeruginosa. Int. J. Antimicrob. Agents, 49 (2), 266-268.

Zhong, D., Brower-Sinning, R., Firek,B., Morowitz, M. J. (2014). Acute appendicitis in children is associated with an abundance of bacteria from the phylum Fusobacteria. J. Pediatr. Surg., 49 (3), 441-446.

Received 3 January 2020

Accepted in the final form 13 February 2020

\section{MIKROBIOTAS BAKTERIOLOG̣ISKA IZVĒRTĒŠANA BĒRNIEM AKŪTA APENDICĪTA GADĪJUMĀ}

Pēdējo gadu laikā ir mainījusies akūta nekomplicēta apendicīta ārstēšanas taktika, kuras ietvaros rekomendēta antibakteriālā terapija nevis kirurğiska operācija, īpaši bērniem. Šì pētījuma mērḳis bija izvērtēt mikrobiotu pediatriska vecuma pacientiem ar akūtu komplicētu un nekomplicētu apendicītu, kā arī izvērtēt etiolog̣isko ierosinātāju antibakteriālo jutību. Darbā tika izmantotas bakterioloğiskās metodes, mikroorganismu identifikācija veikta, izmantojot VITEK2 analizatoru. Antibakteriālās jutības testi tika veikti un rezultāti izvērtēti saskaṇā ar Eiropas antimikrobiālās jutības testēšanas (EUCAST, Versija Nr. 7.0, 2019. g. janvāris) rekomendācijām. Yersinia enterocolitica serodiagnostikā tika izmantota netiešā hemaglutinācijas redakcija. Pētījuma rezultāti liecina, ka ir microbiota atškirības akūta komplicēta un nekomplicēta apendicīta gadījumā. Akūta komplicēta apendicìta gadījumā prevalēja Pseudomonas aeruginosa. Akūtu apendicītu gadījumā pārsvarā izdalītas mikroorganismu asociācijas. No pētījumā iekḷautajiem pacientiem tikai atsevišḳos gadījumos tika izdalīti ESBL producētāji. Daḷa Pseudomonas aeruginosa celmu bija rezistenti pret amoksicilīnu ar klavulānskābi, ertapenēmu, ampicilīnu un cefotaksīmu. Daḷa izdalīto E. coli celmu bija rezistenti pret ampicilīnu un amoksicilīnu ar klavulānskābi. 